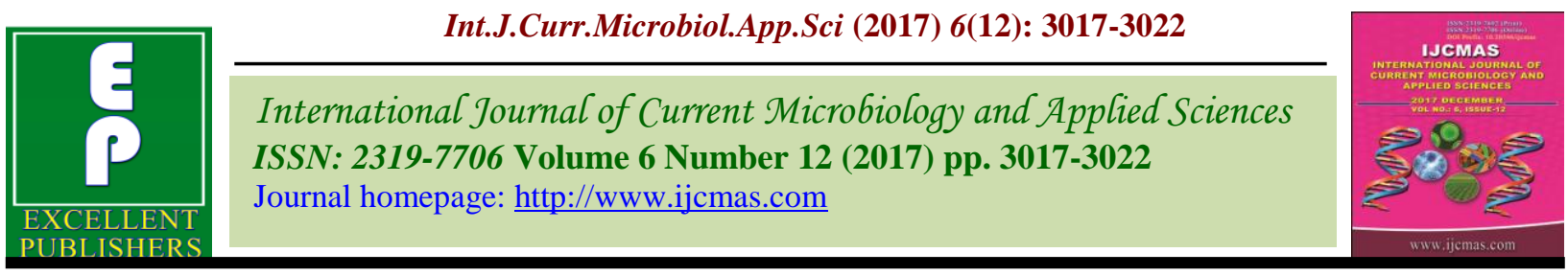

Original Research Article

https://doi.org/10.20546/ijcmas.2017.612.352

\title{
Study the Survivability of Grafts in Different Varieties of Guava (Psidium guajava L.) by Softwood Grafting under Different Growing Conditions
}

\section{G.C. Nanditha*, D.R. Patil, Kulapati Hipparagi, Ambresh, S.N. Patil, Venkateshalu and Kanthesh Gandolkar}

\author{
Department of Fruit Science, Department of Entomology, Department of Agronomy, \\ University of Horticultural Sciences, Bagalkot-587 104 (Karnataka), India \\ *Corresponding author
}

\section{A B S T R A C T}

\begin{tabular}{|l|}
\hline K e y w or d s \\
$\begin{array}{l}\text { Grafts, Survivability, } \\
\text { Softwood grafting, } \\
\text { Open, Shade and mist } \\
\text { house. }\end{array}$ \\
\hline Article Info \\
\hline $\begin{array}{l}\text { Accepted: } \\
\text { 23 October } 2017 \\
\text { Available Online: } \\
\text { 10 December } 2017\end{array}$ \\
\hline
\end{tabular}

\section{Introduction}

Guava (Psidium guajava L.) popularly known as apple of tropics and is native to the tropical America stretching from Mexico to Peru. Although, it is native to tropical America, it is widely distributed throughout the tropical and subtropical regions of the world. At present, major guava producing countries are South Asian countries, the Hawaiian Islands, Cuba and India (Kumar et al., 2011). Guava has been well adopted to India and considered the fruit of masses in terms of availability, nutritional value and price structure in comparison to other fruits (Dinesh and Vasugi, 2010). Guava was introduced to India during $17^{\text {th }}$ century. It thrives well under a wide range of edaphic and climatic conditions. It is a popular fruit crop due to its prolific bearing and good remuneration. Guava plants have been propagated through seeds since long time. Propagation from seeds results in considerable variation in the size, shape and quality of fruits. Vegetative propagation in guava results in true-to-type crop with short juvenile phase. Commercially, guava is propagated by air layering though considered to be most inexpensive method for vegetative propagation, the method did not prove very successful in case of guava due to production of poor quality roots and hence poor field survival (Shashikumar et al., 2012). As a solution to these problems, softwood grafting is easy to handle and quite efficient 
as well as grafts can be prepared within a year, thus reducing cost of raising grafts considerably. Softwood grafting gives an excellent response by higher graft success and survival percentage of quality grafts with the least possibility of mortality which helps in better and uniform orchard establishment (Ram and Pathak, 2006).

Provision of shade during and after grafting was found to have beneficial effect on success of grafting. Light is essential source for triggering photosynthetic activity and there by better nourishment of grafts. The rate of photosynthetic activity varies with the level of shade (Swamy, 1993). So, keeping these points in mind, the present investigation was carried out to assess Studies on the survivability of grafts in different varieties of guava by soft wood grafting under different growing conditions.

\section{Materials and Methods}

An experiment was conducted at Division of Fruit Science, University of Horticultural Sciences, Bagalkot, Karnataka (India) during the year 2015-2016 in a Split plot design. Ten months Sardar (Lucknow-49) rootstocks were raised for soft wood grafting. A total of 480 healthy guava seedlings were used for this experiment.

The softwood grafting of guava was done using Sardar, Allahabad safed, Lalit and Arkakiran were as scions at different growing conditions i.e. Open condition, Shade house, Mist house followed by shade house, Mist house followed by open condition. Observations were recorded on ten grafts in each replication at 30,60 and 90 days after grafting. The data were subjected to statistical analysis as per the procedure outlined by Panse and Sukhatme (1985) and the treatment means were compared by critical difference values computed at $5 \%$ level of significance.

\section{Results and Discussion}

\section{Graft survivability (\%)}

The data on graft survival percentage presented in Table 1 showed that the highest graft survival $(68.96 \%, 60.36 \%$ and 48.11 $\%$ ) was found in mist house followed by shade house at 30, 60 and 90 days respectively after softwood grafting (Table 1). However, the lowest graft survival (48.83\%, $43.02 \%$ and $39.57 \%$ ) was noticed in open condition at 30, 60 and 90 days respectively after softwood grafting. The highest survivability under mist house condition might be due to optimum temperature suitable for new parenchymatous callus proliferation between rootstock and scion and also good callus formation due to higher humidity (Hartmann et al., 1997). The similar results were reported by Desai and Patil (1984) and Sivudu et al., (2014) in mango, Shinde et al., (2010) in jamun. The highest graft survival (73.39 \%, $61.92 \%$ and $54.61 \%$ ) was registered in Sardar at 30, 60 and 90 days respectively after softwood grafting. Whereas, the lowest graft survival $(47.82 \%, 44.66 \%$ and $35.08 \%$ ) was registered in Lalit at 30, 60 and 90 days respectively after softwood grafting. Singh et al., (2007) also reported that significantly higher success of grafts (64.56-94.33\%) in green house compared to open field condition (51.30-78.63\%) in Sardar and Allahabad Safed (Fig. 1, 2 and 3).

Interaction effect showed the highest graft survival $(85.76 \%)$ in Sardar under mist house followed by shade house and the lowest graft survival $(39.97 \%)$ was found in Lalit under open condition at 30 days after grafting. Similar results were obtained by Visen et al., (2010) in guava wherein he got maximum success of grafts $(81.71 \%)$ in Allahabad Safed and Sardar (Lucknow-49) during September to December under greenhouse and minimum in open field conditions. 
Table.1 Graft Survivability

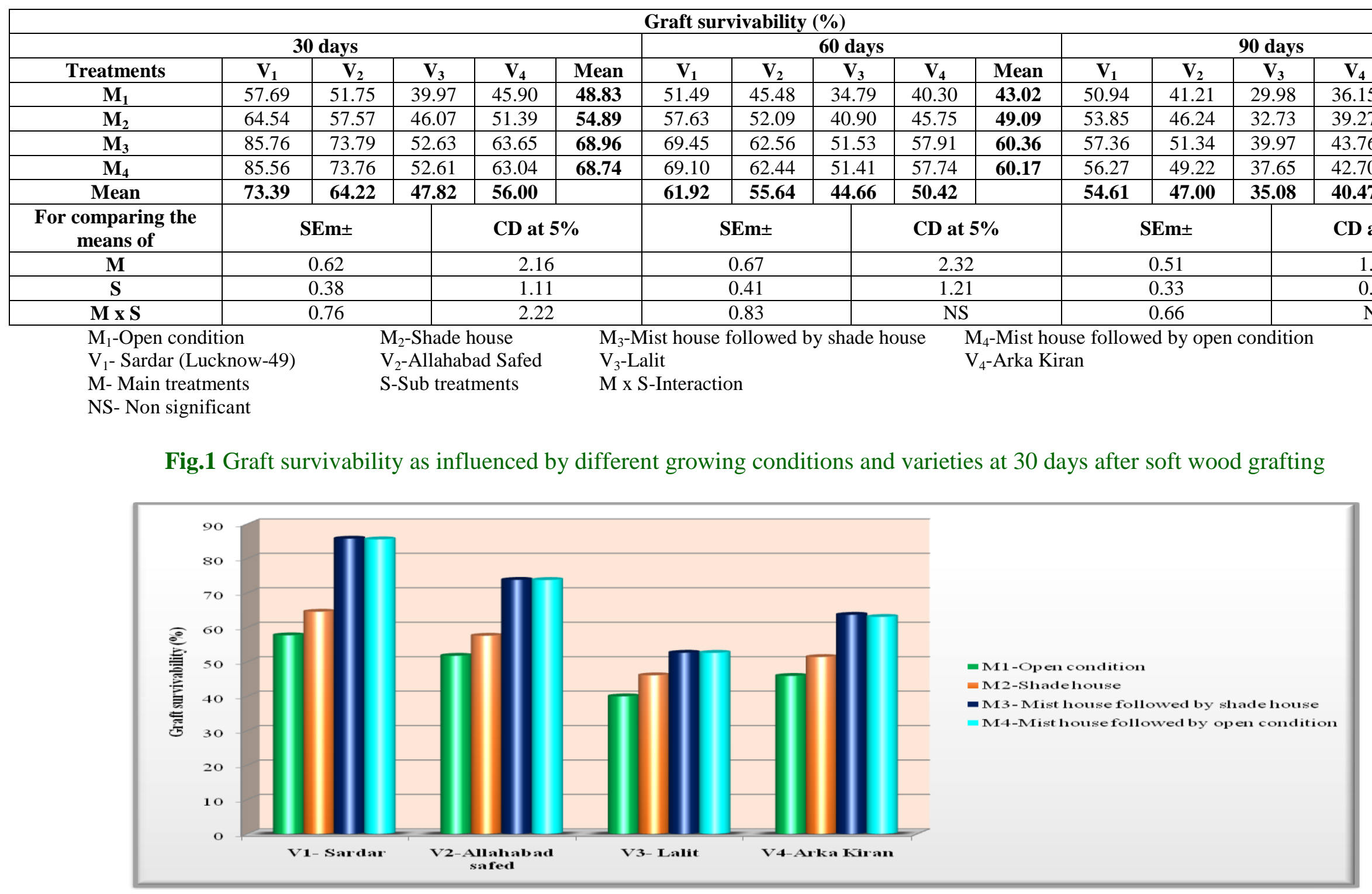


Fig.2 Graft survivability as influenced by different growing conditions and varieties at 60 days after soft wood grafting

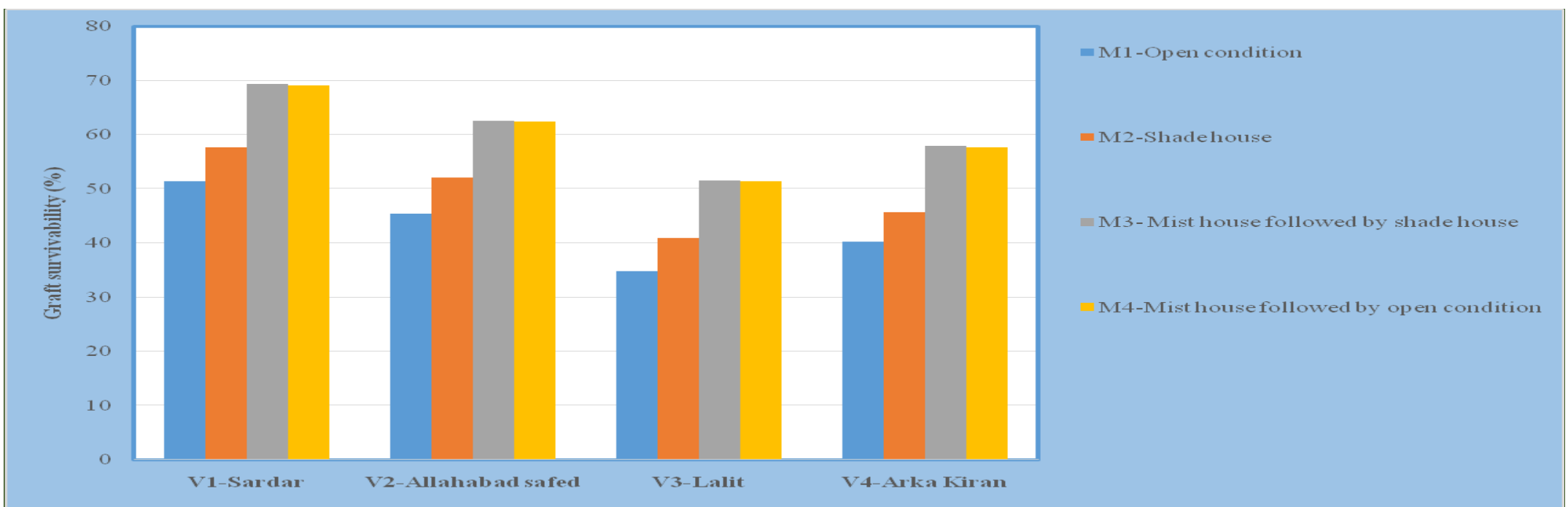

Fig.3 Graft survivability as influenced by different growing conditions and varieties at 90 days after soft wood grafting

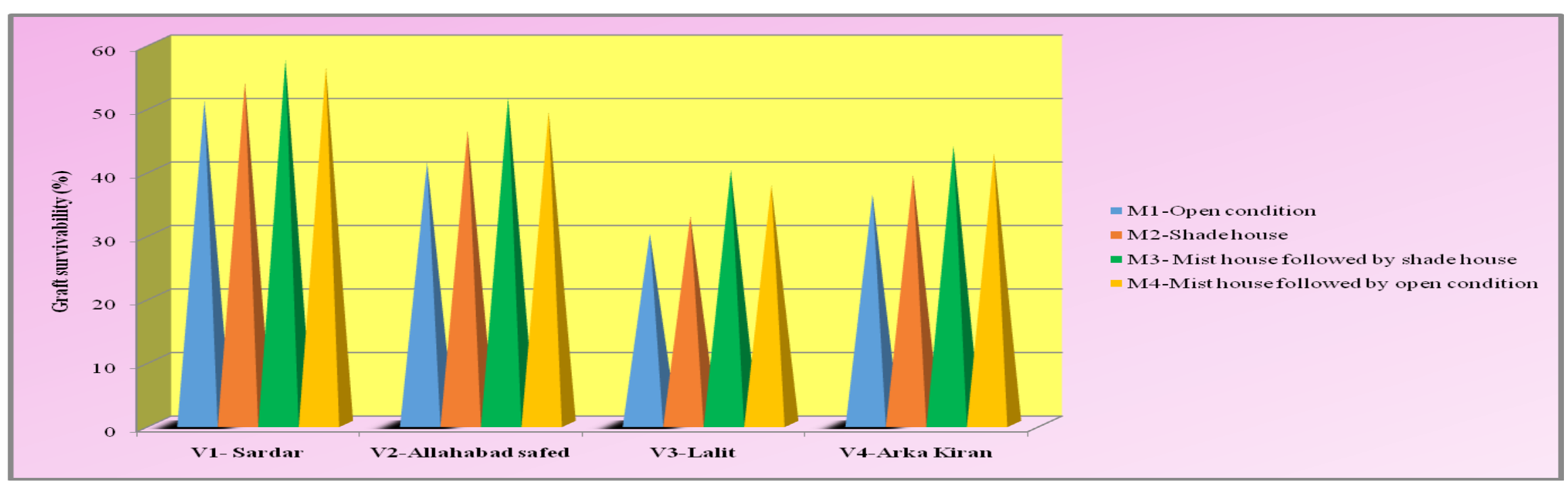


There were no significant differences between different growing conditions and varieties at 60 and 90 days after soft wood grafting.

\section{References}

Desai, J. B. and Patil, V. K., 1984, Success of stone grafting in mango in glass house and in open. Punjab Hort. J., 24:7-10.

Dinesh, M. R. and Vasugi, C., 2010, Guava improvement in India and future needs. J. Hort. Sci., 5 (2): 94-108.

Hartmann, H. P., Kester, D. E., Davies, F. T. and Genene, R. L. 1997, Plant propagation principal and practices $6^{\text {th }}$ ed. Prentice Hall of India Pvt. Ltd., New Delhi, p. 25.

Kumar, B., Mistry, N. C., Singhm, B. and Gandhi, C. P., 2011, Indian Horticulture Database, National Horticulture Board (NHB), Gurgaon. Department of Agriculture and Cooperation, Govt. of India, p. 76-83.

Panse, V. G. and Sukhatme, P. V., 1967, Statistical Methods for Agricultural Workers, ICAR, New Delhi, P: 152161.

Shashikumar, Swamy, G. S. K., Kanamadi, V. C., Gangadharappa, P. M., Prasadkumar, Jagadeesha, R. C. and Jagadeesh, S. L., 2012, Effect of pre- curing of scion on softwood grafting success in guava. Karnataka J. Agri. Sci., 25 (2): 289-290.

Shinde, S. B., Saiyad, M. Y., Jadav, R. D. and Chavda, J. C., 2010, Effect of structural conditions on softwood grafting success and survival of jamun grafts (Syzygium cumini Skeel.). Asian J. Hort., 2 (5): 391-392.

Singh, G, Gupta, S, Mishra, R. and Singh, A., 2007, Technique for rapid multiplication of guava (Psidium guajava L.). Acta Hort., 73 (5): 177183.

Sivudu, B. V., Reddy, M. L. N., Baburatan, P. and Dorajeerao, A. V. D., 2014, Effect of structural conditions on veneer grafting success and survival of mango grafts (Mangifera indica cv. Banganpalli). Plant Arch, 14 (1):71-75.

Swamy, G. S. K., 1993, Standardization of vegetative propagation techniques in jackfruit (Artocarpus heterophyllus Lam.). Ph.D. Thesis, Univ. Agri. Sci., Bangalore, p. 9.

Visen, A., Singh, J. N. and Singh, S. P., 2010, Standardization of wedge grafting in guava under North Indian plains. Indian J. Hort., 67: 111-114.

\section{How to cite this article:}

Nanditha, G.C., D.R. Patil, Kulapati Hipparagi, Ambresh, S.N. Patil, Venkateshalu and Kanthesh Gandolkar. 2017. Study the Survivability of Grafts in Different Varieties of Guava (Psidium guajava L.) by Softwood Grafting under Different Growing Conditions. Int.J.Curr.Microbiol.App.Sci. 6(12): 3017-3022. doi: https://doi.org/10.20546/ijcmas.2017.612.352 